\title{
'Exertion is not connected to success': everyday Yoruba discourse of work and success
}

\author{
Augustine Agwuele
}

\section{Introduction}

The Yoruba saying 'isé o kan oriire', exertion is not connected to success, is very dispiriting to the realists, hard workers and assiduous individuals who, with grit, wrestle success from chance, but comforting to the jolly fellow, the indolent and the leisurely inclined. With a tinge of equanimity, the phrase pacifies both, offering to the indolent succour and justification for their modest estate. Affirming the realist's rationalism, it cloaks them with humility. The language of everyday life bears out some of those realities with which people contend; it brings to the fore their (un)consciousness in their apprehension of those realities and makes intelligible their coping mechanisms. This everyday discourse represents and presents a core reality that requires attention.

Suspended as it were between meritocracy and inevitability, there arises a gnawing suspicion of 'falsehood' in either the impudence or intrepid nature of the first relative to the resigned modesty and fortuitous nature of the latter. Yoruba marshal a host of what some would call 'trivial' or 'circumstantial' evidence, as will be shown, to support the victory lap of the rationalist who considers hard work essential and the mea culpa of the indolent, persuaded of external factors. Yoruba antecessors, having traversed the earth, distilled their observations and conclusions into aphorisms, pithy proverbs and anecdotes. These they bequeath to their progeny, who continue to hand them down intergenerationally. Sourcing from these inchoate ideas, Yoruba conceptualize the human's path to earthly success given the grim repudiation of grit declared in the sentence 'ișé o kan oriire', exertion does not pertain to good fortune or success. My goal is to make sense of the way in which the semantic detritus of the orature reflects a deep-seated belief that finds expression in everyday discourses.

Why do two people, equally endowed, driven and committed to their professions, end up with starkly different results - one wealthy and the other poor? Was there a level playing field to begin with? Is life meritocratic? Watching how one person 'effortlessly' achieves 'oríire', sometimes despite working in a mundane enterprise and perhaps with a laissez-faire disposition, while 'success' eludes another who is more industrious, clever and punctilious, Yoruba conclude that the playing field was never even, that the fate of a person was sealed at the outset. They conclude that there is no link between work and success/good fortune; if there is, then it is tenuous and fleeting. One's kernel is either cracked or not cracked by the gods.

To account for these 'invisible cracking hands' supposedly at work as an explanation for the mysterious incongruity of isé and oríire, Yoruba people lean on their metaphysical history. The flute, they say, echoes only what was blown into it.

\footnotetext{
Augustine Agwuele is a professor of linguistics in the Department of Anthropology at Texas State
} University, San Marcos. Email: aa21@txstate.edu 
People manifest their programmatic content. 'Bi ișẹẹ ò șẹ, ișẹ kii dédé șẹ', were misfortune not instigated, penury wouldn't suddenly occur. This Yoruba saying presaged Newton's first law of motion that a body at rest tends to stay at rest until imposed upon by an outside force, and a body in motion remains so unless it is acted upon by an external force. This Yoruba homeostatic view of an individual seems to suggest that only a greater force could rouse a person from the neutrality of any state.

\section{Context and scope of the article}

Long the domain of professional philosophers, scholars and individually contracted merchants of ideas, insufficient attention is paid to the quotidian life of people in whose daily encounters play out the staples of their disputation: predestination, free will, essence, existentialism and personhood, and so on. While professionals reference the daily pronouncements and reflections of ordinary folks, they mostly abstract away from them, in order to critically, scientifically and formally examine them. Consider the two major concepts in this article: oriire and ènìàn. Generally, the meaning of a concept is a prototype category with members that differ in privilege, possessing properties that vary not only in number and strength but, through their boundaries, also in scope (Lakoff 1987). For example, the prototypical meaning of oriire is success of any kind, the absence of misfortune, or good luck. When someone gives birth, escapes an accident, finds money on the road, buys a car or passes an exam, the standard congratulatory greeting is 'e kú oríire' (well done head good - i.e. congratulations). This expression, of shared happiness, ignores how the joy came about, be it through 'luck' or 'attainment' (àseyori). Of course, achievements are also noted. For example, after securing a salaried job in Lagos, Rasaki returned to Ibadan to visit his mother, Iya Rasaki. He prostrated himself and handed his first salary to her. Iya Rasaki, in tears of joy, prayed for him, saying, among other things, 'àșeyọrí báàyí ni tì ẹ' (such success will always be yours). Then, holding her own head, she rejoiced: 'Mo sé oriire o, elẹdàá mi, mo sé oriire' (I am fortunate, my creator, I am lucky). Neighbours, hearing her, trooped in to offer their 'e kú oríire o'. In return, she said 'ire ákári' (may the goodness spread to all). Every joyful occurrence, be it achieved or ascribed, is success that elicits such standardized congratulatory salutations and responses. Enìyàn ${ }^{1}$ is another concept: the prototypical meaning is a person, a human being, as opposed to eranko, an animal. Ordinary usages include ènìyàn dáradára (good, kind person), olóòtọ ènìyàn (honest person), èèyàn tiwa (our person, i.e. 'homie' (slang)). It could be shortened to ẹni (anyone) and it also includes the notion of personhood, a concept of extensive philosophical inquiry. My focus is on the

\footnotetext{
${ }^{1}$ Capturing the deep meaning of ori, the core of oriire, or engaging with the intense philosophical discourses of personhood (ènìyàn) would distract from this narrowly focused article, as would detailing the nuances surrounding them and related concepts, including their denotations, connotations or entailments. Readers interested in these themes should consult works cited in this article and the references in them. Given my focus on everyday life, specifically outcomes, I am rendering oríire generically as success and ènìyàn as a person, i.e. an individual.
} 
prototypical non-scholarly usage of these phrases by ordinary people, rather than their scholarly, philosophical discourses, on which there are extensive and informative works. As Bréal (1995 [1844]) noted, when people choose a specific word in communication, they choose the word that corresponds to the meaning they intend to express. They leave out all other possible meanings of the chosen word, focusing only on the one that aligns with their thoughts, while other possible meanings continue to exist in their mind. I focus on success or good fortune (oriire) and on individuals or a person (ènìyàn) as found in the use of ordinary language. The discussion in this article draws from data obtained from interactive real-life situations, which academic snobbery can dismissively disparage as mundane, circumstantial, folk thought or trivial. However, scholars who have explored such ordinary things - including trivial productions such as Onitsha market literature (Obiechina 1972) - have found them particularly useful for understanding existential tensions, for the exposition of realistic and popular cultural manifestations, and for the interpretation of ordinary life and orature (Barber 1997), as well as functioning as a repository of cultural knowledge (Owomoyela 2005). As Achebe noted, African literary novels and short stories draw from a common oral heritage (see Achebe and Innes 1985). Orature has not only shaped African literature and humanities outputs; it has also distinctively informed Africans' responses to life. Scholars have noted the centrality of orature and narrative not only as a mode of thought but as an apprehension of reality (MacIntyre 1981), construction of the self and common identities (McAdams 1993), and certainly a means of explaining causality and personal experiences. Importantly, these and related works critically display the values of the mundane as unfiltered data on a people's cultural map. I show that speakers' language use marks their positionality within the Yoruba conventional map of social reality.

The focus on Yoruba people's routine explanations for their daily realities, especially in coping with the conundrum of work and success, as adopted for this article, recognizes the importance of individuals' pronouncements; gives weight to their lexical choices, stories and anecdotes; and puts aside the academic perception of them as prosaic. According them significance supplements the vital contributions of professional thinkers' elucidation of the world sense of African peoples, especially inquiries into the adequacy of indigenous thought and practices as philosophical material. Early post-independence philosophical inquiries pitted philosophers of African descent (e.g. Hountondji 1983) against their compatriots (e.g. Gyekye 1992; 1996; Wiredu 1980), especially concerning the value of orature as philosophical material and whether philosophizing is itself a cultural practice or not. Hountondji's early works proclaimed the universality of the 'individualized' Western model of reasoning, while Gyekye, in rejecting the universalism of the Western repertoire, suggests that philosophy exists because there are, in every culture, those predisposed to engage in deep reflections and who pose critical and fundamental questions about the human condition. Seeing philosophy as a cultural practice, Gyekye prefers to elevate indigenous African views and oral sources as philosophical material. Even a cursory observation of Africans in their general mode of discourse would most certainly affirm the centrality of indigenous views as contained in their various oral sources as essential material informing not only critical inquiry but also the metalanguage of critical inquiry. One of the most sustained engagements with Yoruba conceptualizations of destiny is in philosophy and religious studies. Yoruba professionals, using their training and emic perspectives, elucidate the 
Yoruba understanding of human personality (Abimbola 1971; Abiodun 1981; 1987; Akin-Makinde 1984); offer critical expositions of Yoruba belief (Hallen and Sodipo 1986), including their value system (Babatunde 1992); and account for their culture (Abimbola 2006). Others theorize Yoruba life in the context of ori and human destiny (Makinde 1985; Oladipo 1992; Oduwole 1996; Gbadegesin 2003). These and related works, not cited here, are authoritative on these themes and of immense value. They have variously explicated the core concepts around which this article revolves, thus freeing me to focus on the unguarded utterances of Yoruba people in their everyday pursuits.

In offering a realistic, experiential discussion of people's appraisal of and response to the illogical connection between work, isé, and success, oríire, it is necessary to shift attention to spontaneous common-sensical performative actions of people in their daily pursuits. This shift in attention does not mean a disregard of scholarly sources, some of which contain data from daily lives and popular expressions, as previously noted. Rather, it means supplementing scholarly disputations with a discussion that foregrounds the day-to-day. It means privileging the everyday thoughts operational in the life of individuals that appear circumstantial and humdrum but nevertheless are consequential, revealing themselves as the core belief system of a people despite academic attainment, religion, profession and status. Thus, I explore extant Yoruba conceptualizations of this conundrum by assaying core ideas in regular folks' outlook as revealed in their orature - sayings, apophthegms, proverbs and retorts - which they deploy in everyday discourses and in regular interactions.

\section{Culture}

To explain Yoruba ruminations, I take culture to be an internalized system of knowledge that is common to a people and can be externalized in commonly recognizable language and actions. The internalized knowledge system includes those presuppositions implied within the state envisioned by an utterance (implicatures) and without which it is difficult to make sense of the world in which such an utterance occurs (entailment). These are the "cultural specific assumptions that have to be characterized in order to understand various aspects of speech acts in a given culture' (Lakoff 1974: x). Subsuming internalized and manifest components of a culture, reality presents itself in those daily interpersonal interactions and utterances of ordinary people. It occurs in those naturalistic data that are different from the estranged examples of professional traders in ideas. These daily manifestations are in and of themselves data of inquiry that require no further justification for their foundation; this is even more true given that the sayings, aphorisms, proverbs - indeed the pronouncements - of regular people are objectivated beliefs and strong instances of intersubjectivity.

\section{Sources of information and approach}

Not every subject matter - and especially not a people's unfiltered reactions to life - can be most profitably studied by sampling a few preselected interviewees, 
at selected locations, who are interviewed using carefully constructed research instruments geared towards obtaining a consensus on standardized questions (Romney and Moore 1998). As Nyamnjoh (2005) artfully articulated: 'Subjective and intersubjective accounts sometimes say much more than a dull and phony objectivity.' As a lifelong scholar, invested in day-to-day life, fieldwork is built into my interactions; while formal research has an invaluable place, the ethnographic data presented here were 'collected' over several years and in the course of unscripted real-life interactions, encounters and unpremeditated conversations among Yoruba people, primarily in Ibadan, Lagos and outside Nigeria. I exploited chance occurrences such as birthdays, social gatherings, offhand discussions with friends and colleagues, visits to neighbourhood acquaintances, reunions with high-school friends and any chance meeting that afforded moments to muse about life, family, job and health, among other things, and to pose questions about 'ișé o kan oriire'. Rarely would a Yoruba pass up the opportunity to discuss topics of universal concern. Sometimes, listeners simply join in these informal conversations, under the guise of 'àisí mbẹ $n i$ aidási' (to not be present is to not participate). Having cultivated curiosity, I sometimes asked if I could record or write down what was being said because I thought it was important. Such requests were always granted with me being called alákọwé - bookworm, a term of endearment. As I will show, the mindset that is revealed through these conversations and everyday orature does not depend on education, religious confession or attainment. Finally, the style, tone and mode of presentation in this article are purposefully designed to align with everyday discourses, the content and focus of the article. It is important to restate that this is not a philosophical work, but a discourse ${ }^{2}$ analysis-cum-linguistic explanation of utterances with the aim of uncovering a person's view of fortune or misfortune.

\section{Oriire and ènìyàn}

The two noun categories contrasted in the saying ișé (work) and oriire (success) need some explanation. Oríire derives from two nouns: ori and ire (rere). Orí (head) is synonymous with summit and faculty, among other meanings. Ire (good) denotes success, goodness and good fortune. The antonym of oriire is oriburúkú. This is composed of the root noun orí and the adjectival suffix burúkú (bad) and connotes failure, misfortune and misery. The concepts oriire and oriburúku are underdetermined in explaining the good fortune, success, achievements or failures of an individual as a function of orí.

Yoruba people's understanding of good fortune and misfortune is rooted in their origination history. A person comes from orí, the head, during creation. First, the arch-divinity constructs a lifeless human form. Olodumare, the supreme deity, invigorates the lifeless human form by breathing into it.

\footnotetext{
${ }^{2}$ Research questions determine approach, method and analysis; my focus is on reasoning out manifest 'intuitive' responses, the circumstances of which could not have been predetermined. Actual life does not mirror laboratory observations. To contrive situations and observe responses would be a simulation of reality. The data presented here focus on the saying 'ișé o kan oriire'. This article should be read against the backdrop of the 'data', the subject, and its interactive nature.
} 
However, the newly animated being, consisting of body and the breath of life, is incomplete because it lacks purpose. Its purpose or direction is moulded into orí, head, by Ajala, the head-maker. This living being goes to Ajala to obtain its orí - i.e. its destiny - through: (1) pre-allocation, ipin-orí; (2) kneeling to choose, akunleyan; (3) accepted while kneeling, akunlegba; or (4) predestination, ayanmo (see Gbadegesin 2004; Ekanola 2006; Balogun 2007). Once obtained, the content or quality (good or bad) of the ori is not revealed to the person. Ori is the sealed earthly possibilities, attainment and roadmap of a person. As the summit of a person, ori is metaphorically indexed by the physical head. Once obtained, ori is believed to be permanent and undeniable.

The permanence and faithfulness of ori to an individual is emphatically narrated in the Ifa verse Ogunda Meji. In the narration, each of the gods is asked if any of them is ready and willing to accompany their devotees to their graves. None of the gods agrees to die with any of their devotees. Orunmila shudders at the idea, and pronounces saying, it is only the ori of a person that accompanies an individual to their grave. For this reason, the Ifa verse concludes that there is no god (orisa) who can bless a person as much as the person's ori. For this reason, people are enjoined to worship, petition ori rather than the gods. (Gbadegesin 2004: 313)

Far from being a tarradiddle that 'rational' people would most certainly ignore or excuse, the reality of this Yoruba account is revealed in people's daily words and actions, regardless of their social standing, hence the attention to them. It is perhaps noteworthy that all people have their origin story on which their world sense is anchored. Such origin stories are timeless and 'rigid' in essence, but retelling them does not imply rigidity or timelessness in people's life and views.

The noun 'ișe' translates as 'deeds'; any line of work is iṣé. In the context of a person, the interaction of ori and ișé is as complex as it is contentious. Underlying this is the idea of determinism, a recalcitrant theme of vigorous debates and expositions among Yoruba thinkers such as Olusegun Oladipo, Segun Gbadegesin, Kola Abimbola and scholar and diviner Wande Abimbola, among many others. The popularity of the tension between ori and iṣe is not due to professionals whose ișé (job) it is to engage it in this way; after all, that is the route that their ori has chosen for them to earn their keep. Rather, it owes it to its pervasiveness across the nation: it is in the social consciousness of individuals and it occurs in the 'therapy sessions' of everyday interactions, and it is a constant in popular arts, theatre and now films. Together, these outlets explore the incommensurability of efforts, investments and exertions with disparate results within a cultural creed that suggests prior and inflexible constraints. Inescapably bound to and unable to transcend the natural, a person's thoughts, reflections and imagination are a reification of that which is a thesis and antithesis of their observable reality onto which success is projected or against which it is opposed. These observable worlds provide the data - seldom sought but nevertheless real - and the orientations towards the search for values, as well as the structure for their valuation. Consider Senior Abel. He was four years ahead of us in high school, hence the customary polite term of address 'senior'. His good friend was Senior Achipelago. They were fixtures at Metho solely on account of their 'journey'. Senior Abel, as three other schoolmates recalled during a reunion, was very gentle and generous with knowledge. He tutored the majority of us in maths, his forte. Yet he kept 
failing final exams despite a brilliant performance during the term and he kept repeating grades. We caught up with him in Form 4 (junior high school). Because of his failures, he was very studious. His progress, according to a friend, who was explaining why we caught up with him in Form 4, was held up by 'worldly forces', àwon-ayé. I asked him how he could make such a claim despite his education. He responded saying: 'Look, let me tell you, there is ayé [evil forces]. They tethered his progress like a manual clock. Once wound, it ticks and keeps time, but will stop after a length of time. He will run well but peter out shortly before the summit.' The third friend chimed in: 'Without intervention, his results would not reflect his efforts.' Becoming emotional, he lamented, 'Omo ológo de ni senior yẹn' (That senior was such a glorious person). His otherwise great fortune and gifts were being frustrated from within his household (ogun ilé). By this, he referred to the established belief that jealousy could cause family members, especially in a polygamous home, to stymie a person's success. Finally, the second friend, who is now a pastor, said: 'Olorun a ti ba won tu ide yen' (God would have unchained his bondage). Their collective views affirm that 'ișé o kan oríire'. Importantly, they pointed to the possibility of derailing a destiny and of finding relief.

A person, at the moment of creation, seems an embodiment of contradiction. The head, orí, bears an indelible imprint of a person's life content but radically opposes their limbs, owó, and the legs, esèe, both instruments of exertion. Why would one need legs if there were not a competitive race, 'eré ije', and what use are hands if there are no fights to be fought? In his discussion of the nature of a person, Abimbola (2006: 80) explicated esè , legs, as 'strife', 'hard work' and 'struggle'. To him, humans possess esè to actualize the potentials contained in their orí. The mobility involved in eseè is a vital component of a person, metaphysically and physically, and it metaphorizes the exertions inherent in a person's earthly journey, seen as a peregrination, 'irìn-àjò ẹda laye'. It occurs in the search for three main blessings or ire: financial blessings, ire-owó; blessings of children, ire-omo; and blessing of longevity, ire-àiku. These three requisites of life constitute the spondulicks around which Yoruba obsess. According to an Ifa verse - eji ogbe:
Oríire ni d'ade owo
A fortunate head wears a bejewelled crown
Orun ire ni șediga ilẹke
Idirere ni fi enni ore site
A fortunate neck is adorned by jasper beads
A fortunate behind sits on a mat of honour

Given the stewardship of orí, a regular Yoruba prayer is 'May my inner head not undo [the exertions of] my outer head' - 'Kí orí-inú mi má ba t'òde mi jẹ.' This prayer speaks to the possibility of conflict between the presumed steering inner, pre-chosen head and the outer, actuating head. As conscious beings, humans possess thoughts, desires and aspirations. Given that the contents of the selected inner ori are unknown to orí-ode, the outer head (i.e. the thinking being), it is possible for a person's thoughts to antagonize their predetermined aspirations (Babatunde 1992: 13333). Anxious about the possible clash between ori and self,

\footnotetext{
${ }^{3}$ The three Yoruba life pursuits and Babatunde's explanation of work, esè̀, are Yoruba oral heritage and not an outcrop of any cited person's original intellectual rumination. Babatunde's scholarly explications, however, bring more clarity to them.
} 
and about the prospect of their own exertions nullifying the pre-ordained, Yoruba make the plea cited above. Where such a conflict occurs, Yoruba ascribe the contrary relationship to a person's ignorance of the content of their orí. As a result of this, they anxiously engage esè (legs) to hasten ahead of and get out of sync with orí. But is it fair to charge a person with embodying contradiction? Why would a person whose ori already has a pre-written content be saddled with a consciousness and limbs - owó and esè - instruments of exertion? Before taking a closer look at spontaneous Yoruba views of this apparent dissonance, the two readings of the title phrase require clarification.

\section{Readings of 'iṣe o kan oriïre'}

'Isẹe o kan oríire' (iṣẹ: work; o: not; kan: affect; oriire: success) denotes the Yoruba perception that a type of profession does not have a bearing on, hence leading to or determining success. While requirements differ in agrarian and contemporary capitalist economy professions and occupations, all individuals seek to attain the three aforementioned defining Yoruba earthly goals. Thus, they say 'sisé sisé lo jare ișé', 'the one who works hard gets the better of poverty'. The blacksmith, fisherman, farmer, merchant, banker, teacher, investor, manufacturer and artist all toil daily to attain these Yoruba life goals. None considers - or accepts - the idea that their choice of profession may prevent them from attaining great success. Convinced that 'one's labour feeds one', 'idi ișé ẹni lati ń'jẹ', Yoruba preach earnestness. Persuaded that 'within one's daily labour lies success', 'nínú ilàkàkà ẹdá ló timá bá oríire pàdé', they reject indolence. And, with an empiricist bent, they claim that their 'own hands bear no deception', 'àtéle owọ ẹni kì tan ní jẹe'. When literacy increased, D. O. Fagunwa 'canonized' this established view and attitude to labour with his children's poem titled Ișé l'ogun ișẹ. In vividly familiar language, Fagunwa caught the popular imagination, turning his poem into an indelible didactic instrument across the Yoruba nation.

\begin{tabular}{|c|c|}
\hline Ișẹ l'ògùn ìṣẹ & Work is the antidote of poverty \\
\hline Ișé la fí n’dẹni giga & Work confers greatness ... \\
\hline bí a ko bá rẹni gbệkẹlé & Where we lack a support system \\
\hline À tẹra mọ 'ṣe ẹni & We simply work harder \\
\hline Ohun tí a kò ba jì yà fún & Whatever one does not earn the hard way \\
\hline kî̀ lè tójọọ & Is often transient - wasted \\
\hline hun tí a bá fara sișé fún & That which one obtains from serious labour \\
\hline i ípe lộwọ́ ẹni & Is enduring \\
\hline Apá lará & Your arm is kin \\
\hline İgùnpá nìye & The elbow is a sibling \\
\hline
\end{tabular}

In extolling the value of work, Yoruba project it as the only panacea for poverty, the sole means to prosperity and comfort, claiming that the only thing that endures and increases is that which an individual legitimately acquires through their own labour and sweat - whatever the occupation. Yoruba say, 'Only the head knows the line of trade that would lead to success', 'Orí lo mo òwò asela'. Individuals, rather than being fixated on one path, should be dynamic and ever ready to diversify their skills and ventures. During a casual dinner organized by a friend in Lagos for his colleague who was locating to Abuja, I sat next to Madam Koselle, who was introduced as a banker. As we chatted, someone 
asked her if she had crossed paths with another friend who also studied accountancy at the University of Nigeria, Nsukka. Madam Koselle said that she did not major in accountancy but in engineering. Now interested, I asked how the transition to banking occurred. In her explanation, she said:

You know, the important thing was to gain admission - only in rare cases does your major really matter. I wanted to do computer science, but I only made the cut-off point for environmental engineering and not computer science, my choice. I graduated with honours and was offered graduate assistantship. By my final year, however, my father had lost his money. I then began to fend for myself and my siblings. I knew that the salary of a graduate assistant would not meet my own needs let alone support my siblings. Immediately I started Youth Service, I did all I could to get into banking. I was lucky - I met someone who helped me do my Youth Service in the bank, and eventually I became a full-time employee. That was twelve years ago. My husband studied mechanical engineering. He delights in repairing cars and appliances; however, by the time I met him, he was working for an insurance firm.

Madam Koselle concluded her personal narrative by saying 'Nínú ilàkàkà ẹdá ló timá bá oríire pàdé' (In one's struggle lies one's good fortune - in reference to being helped to serve at the bank) and repeated a popular Yoruba prayer asking 'orí to give one the right connection', 'k'órí gbé aláwo 're k'oni'. This is not an unusual story; others, as will be shown later, confirm this entrenched view. The taxi driver, tailor, street hawker, itinerant shoe repairer, industrialist, car dealer, professor, civil servant and politician - each one accepts their job only as their current occupation and 'a path to wealth', ònà-ọlà, if so destined by orí. There are 'many roads to the market', Madam Koselle reminded me, and 'this accounts for why a teacher moonlights as a palm-wine tapper', 'ọnà kan ò wojà, ó dífá fún tísà tí $n$ 'kọpe'. The following recorded histories of wealthy Yoruba attest this first sense of the phrase.

\section{Candido Joao Da Rocha}

Da Rocha (1860-1959), famously known as Darosa, is canonized in a popular saying against spendthrifts. 'O ro pe Darosa ni mi', 'Don't take me for Darosa'. And 'Omo Darosa ni e ni?', 'Are you Darosa's child?' Darosa was one of preindependence Nigeria's first millionaires - if not the first. He made his money selling water in Lagos, where he constructed the city's first water fountain and borehole. Known as Iju Water Works, his company supplied water to the entire Lagos district. His major contractor was the colonial administration, which paid him substantially for his services until the government eventually acquired the water project. He is memorialized in the narratives of eyewitnesses who reported how, from the balcony of his house, he would throw coins at numerous children who fought over them. He later expanded his business interests to include restaurants and deep-sea fishing. He lived to be old and his descendants have continued to be prominent in Nigeria.

\section{Taiwo Theophilus Olunaike}

Ori mi pe bi Alajo Shomolu ti o fi ọdun mẹta gbajọ lowo ẹbegberun eniyan lai ko oruko kankan sile, nigba ti o fe sanwo ko si sii owo san fun ẹikẹni. 
I am as sharp as Alajo Shomolu, who for three years collected daily thrifty savings from thousands of customers without writing down a single name and amount. Yet he refunded each without error.

Taiwo (1915-2012) migrated to Lagos from Isonyin Ijebu in search of education in 1926. He completed his primary education in 1934, then became apprenticed as a tailor and was certified after nine years. In 1950, he joined his uncle on a commercial trip to Cameroon, where he tried out different businesses with minimal success. While in Cameroon, he met a neighbour who introduced him to the micro-savings business. He returned to Lagos in 1954 to practise this new line of business. He operated in Shomolu, Lagos, an area popular with small market businesses and traders. He walked daily through the market, encouraging market women and men to save with him, on a daily basis, any amount that they could afford. After an agreed length of time, he returned their contributions to them. His commission at the end of each month was a day's contribution. Contributors accessed loans from him without collateral. Renowned for his memory, honesty and astuteness, he entered into Yoruba folklore having amassed riches from the collection of money (aajo) at Shomolu (Alajo Shomolu). He lived to be old and was survived by many children.

\section{Sir Mobolaji Bank-Anthony}

After his secondary education, Mobolaji (1907-91) worked as a junior clerk in the correspondence section of the Post and Telegraphs Department of the colonial administration in Lagos. In 1931, he decided to go into business. He travelled to Germany and England to study how to make palm oil and then established M. de Bank Brothers to trade in palm oil and patent medicine. However, these businesses failed. He rethought his focus and worked harder, this time trading in watches. His success, however, was to come from importing and selling fountain pens. He became the largest individual marketer of pens in West Africa, outdone only by the United African Company and the United Trading Company. A 1965 Time magazine article profiled him as one of the richest Nigerians. At his death in 1991, he held the chieftaincy title of Baloro of Lagos (Father of Wealth of Lagos). He was survived by children and grandchildren. As of March 2020, ${ }^{4}$ newspapers in Nigeria were still reporting the drama surrounding his estate.

None of the people discussed above practised what they had initially trained to do. These examples - and many more that could be cited - confirm the Yoruba view that there is no particular route to success or good fortune. The eventual success of these figures was due not to a specific trade but to hard work. One sold water, another pens, and the third helped traders to save. Yoruba therefore rail against idleness; as Pa Òkò, our Yoruba teacher at Metho who was famous for his proverbs during morning assembly, would say: 'You did not slice a groove into the palm tree; you did not wound it with a dart, standing by the palm tree, you

\footnotetext{
${ }^{4}$ See $\quad<$ https://www.vanguardngr.com/2020/03/tussle-over-mbas-property-businesswoman-slamsn10m-suit-against-ig-others/>, accessed 4 April 2020.
} 
open your mouth in expectation. Does palm wine flow freely?', 'Oò dá ẹmu lọgbẹ, oò tà ògùrọ lơfà, o dé idí ọpe, o gbẹnu' ókè, òfẹ níi'ro ni?' It is for an individual to work and it is for ori to grant success. Despite this view, Yoruba also say that 'to toil endlessly like a slave does not guarantee riches', 'ká șiṣẹ bí ẹrú ò pé a lówó'. This brings to the fore the second reading of 'iṣe o kan oríire'.

\section{Second reading: connotation}

Whereas the first reading pertains to the choice of profession, the second reading speaks to the notion of work itself. To toil, exert oneself and assiduously devote oneself to labour does not yield success by itself. Thus, repudiating work as a phenomenon, Yoruba declare that success is unconnected to toil. The successful person is one with 'a good head, not necessarily the one that toils the hardest'.

$\begin{array}{ll}\text { Eni to gbọn } & \text { He who is wise } \\ \text { Ori e l'o ni o gbon } & \text { Is made wise by his orí } \\ \text { Eeyan ti o gbọn } & \text { He who is not wise } \\ \text { Orí re lo ni o go j'usu lọ } & \text { Is made more foolish than a piece of yam by his orí. }\end{array}$

If one's chosen ori contains wealth, toiling will neither hinder nor accelerate a person's path to wealth. Interpreting the verse Ogunda Meji in the Ifa corpus, Gbadegesin (2004) showed the permanence and importance of orí. According to these verses, the supreme gods asked each of the deities whether they were willing to accompany their devotees to their graves. Each refused, including Orunmila, the pre-eminent god, who then concluded by saying: 'It is only a person's ori that will go with him or her to the grave'. As such, ori is the paramount god of a person; orí is to be worshipped and venerated in place of the deities. Orí is the only constant in a person's life. This saying is not an isolated one: during the reunion with three former high school friends, when we mused about Senior Abel, we engaged in a banter of sayings as the discussion snowballed. I responded to the submission of the third friend with 'Ișé ko kan isẹe beeni ko difa fun oríire', 'Work neither relates to poverty nor implicates success'. He replied: 'Ișé ko lowo', 'Work is not money or wealth'; 'Kirakita o mọla', 'Endless exertion does not yield wealth'; 'Ki a șiṣe bi ẹru ko da nkan', 'To labour like slaves amounts to nothing'.

The second friend added: 'Șiṣe bi erin, je ije iliri', 'Work like an elephant for a mouse-sized meal'. And the third, the pastor, retorted with: 'Inu ire o kan oríire, inu buruku o kan oṣi', 'Kindness does not yield success, wickedness does not foreswear poverty'. These aligning sayings reflect a shared belief.

During the sixty-fifth birthday of a prominent Ibadan man, which was attended by kings and governors, I repeated my remarks above to Mr Oloyede, an elderly man who shared a table with me and was lost in thought. He looked at me and nodded his head in agreement. Then he said, 'K'oórí gbé aláwo're ko'ni' (May ori connect one with the right enabler) and proceeded to talk about Bola, his neighbours' son. Bola had submitted hundreds of applications across several states and was still jobless six years after graduating top of his class. Returning

${ }^{5}$ Abimbola (1977: 176). 
one day from job hunting, he saw a man's wallet drop as the man entered a car and drove off. Using the business card in the wallet, he traced the man and returned the wallet with its contents intact. Surprised that an unemployed person would return such a wallet despite all the money in it, the man offered him a managerial position with an official residence, vehicle and high salary. It turned out that the man was the CEO of one of the companies to which Bola had previously applied. Since story begets story, a couple sharing the table with us joined in. The husband told of Baba-Taju, a taxi driver, who was suffering serious financial hardship. He had a passenger who was a young lady who had fought her parents, rejected all their money and decided to break out on her own. When she reached into her bag to pay the driver, Baba-Taju, she found wads of bills. Angrily, she called her parents and told them that, since they had surreptitiously put money in her bag, she would give it away, because they thought she could not survive without them but she was determined to make it on her own. She suddenly looked at the taxi driver and handed the money to him. Overjoyed, Baba-Taju solved his immediate problems and expanded his business. The man concluded, saying: 'The water that one will drink on earth will not pass one by', 'Omi tí ẹdá bá má mu layé yì, kó ní kojá ẹ’. He added:

Kirakita ko, igbiyanju ko - adẹda nikan lo mo ona ẹda. Bi a sare titi bi a tie sare rara, ohun ti Olorun ba ni ko șe naa ni o papa șe.

It is not by exertion, it is not by efforts - only the creator knows the path of the created. Whether one runs endlessly or does not run at all, whatever god decrees will eventually be.

Overwhelmed by the moment, the man celebrating his sixty-fifth birthday reflected on his professional success and declared:

Oríbámidé ni àwọn iṣe yẹn [those jobs come through ori]. I am a Yoruba historian not a scientist or doctor. Who would ever have imagined that I could achieve such great fame and success in America merely by working hard at recounting my people's history? Ori ni, ori $n i$ [it is ori, it is ori].

His comment reminded me of the sayings of the elders that:

Ka sare tete

Ka lo re ka osan mu

Ka rin gbede gbede

Ka lo re ka osan mu

Oba oke nikan lo mo

enitiyio fi osan rere le lowo
To dash quickly

To pluck oranges

To walk leisurely

To pluck oranges

Only the creator knows to

whom to hand good oranges

Even though the Yoruba nation is strongly gerontocratic and defined by hierarchy, such that order of birth confers immense privileges, structures social distance and configures duties and expectations, when it comes to riches the idea of a 'ladder' the most rigidly entrenched feature of Yoruba life, which asks each to await their turn - is nullified. This is captured by the proverb:

Àtètèdáyé ò kan tọro; Olorun ní n̦ṣe orí owó.

Primogeniture pertains not to wealth; God assigns wealth to heads. (Owomoyela 2005) 
In privileging ori as the source of wealth, they say that age is no guarantee of wealth - the traditional education forcefully inflicted on children to learn the importance of ranking by age and to dutifully attend to privileges synonymous with age is immediately overthrown by 'success'. Consequently, Yoruba say 'money outranks [birth] seniority', 'owó gb ẹ̀gbọn'.

\section{Conundrum: isé (work), ìsèé (poverty), oriire (success)}

Pẹki nmo ko, wara mo yaa, onit'ọn ri ibi ti yio ya si ni o.

It confronted me ever so suddenly and promptly I ducked, that is because there was an escape route.

Mr Ola, who resides in Chicago, repeated the above proverb during a phone conversation when, out of frustration, he talked about his pastor who had been preaching about investments. According to him, his pastor made his first million during the 2008 recession. Ceaselessly recounting this success, he tells his congregation to buy distressed properties and await their appreciation. $\mathrm{Mr}$ Ola, who has just bought his first house in the suburbs after years of renting and saving, now weary of his pastor's message, said:

We were not stupid in 2008. How many of us had such cash at hand? Aímó se kó, orí ni [it's not ignorance, it's ori]. Banks were not lending. Look how long it has taken me to save up for this house. Ibi ojà gbé ntà lè mbérè ẹ ò bèrè lowo orí [you are inquiring about lucrative business locations; you are not entreating ori].

It is not about knowing where goods move quickly and profitably; rather, it is ori that sanctions a location and goods as a person's space of, and means to, wealth, he said. It is presumed that 'one's place of wealth', ibi ọla ẹni, is unique. After all, 'not even identical twins come with a uniform orí, each is selected differently', 'ibi tí Táyé ti gbé yan orí kọ ni Kệhìné ti yan ti ẹ’.

The two readings unequivocally affirm the marginal role of the type of work and of working hard in achieving success. Both readings endorse the primacy of ori in determining success. A closer observation of Yoruba words and deeds, however, suggests that this primacy does not exculpate work, and that the opposition between orí and iṣé may be false.

\section{Conundrum: 'ó tún kù' - there yet is}

The previously narrated creation story furnishes the genesis of the Yoruba conceptualization of human nature and purpose. According to this history, things happening to the individual as they walk the earth and their ultimate end are contingent on pre-existing events with which they align. Nothing, therefore, could have been otherwise. In fact, there are no other outcomes aside from the predetermined. For a person to have the freedom to select 'success' or 'failure' would mean that (1) those options remain open to them and (2) they are at liberty to choose anew. Having a choice on earth about the eventual outcome would mean having the ability to undo the initial choice. However, the predestined 
subsumes everything, leaving no room for alternative outcomes. The outcome is inevitable; all efforts are in vain. Consequently, Yoruba say 'ẹdá kàn n'sáré lásán ni', 'humans exert for nought'. Human existence unfolds consistently and consistently unfolds ori's content. Nevertheless, 'the average Yoruba acts as if destiny is alterable. Therefore, even if a bad destiny has been imposed on one, one has a responsibility to change it for the better' (Gbadegesin 2004: 116).

Interestingly, individuals earnestly persist in entreating ori to 'connect them with harbingers of blessings', ' $k$ 'órí gbé aláwo ire koni'. People also ask their ori to fight for them - ' $k$ 'órí mi jà fún mi' - and beg the 'repairer of the head' to save their orí from misfortune: 'Atórísé, orí mí o gbọdọ bùrú o.' Those who are firmly persuaded of the inevitability of ori should not engage in these sorts of prayers. To utter such prayers and still claim that 'there is no potion against destiny', 'àyànmọ ò gbọ ògùn, orí lẹlẹ jjọ', is contradictory. Dr Alao, ${ }^{6}$ a friend, called to say hello. After catching up on family and work, he inquired about a friend who was applying for jobs. I told him what I knew, and he said, 'There is nothing prayers cannot do.' I said that is something that has been bothering me. If indeed prayers can do all things, why then do our fathers say 'àyànmó ò gbó ògùn, orí lẹlé'jọ'? Do you think they were wrong? 'No, they were not wrong,' he replied. Then I asked: 'You go to church and you pray. Why do you pray if they were right?' He replied: 'We pray so that we can align our wishes and desires with the choice of our orí. We should be in consonance with àyànmó rather than kicking against it. If we desire what was not programmed for us, then conflict arises, unsatisfaction ensues, and we lose peace. Our prayers focus on asking for the revelation of that which God has purposed for us.' Essentially, prayers are not to change the situation but to make a person acquiesce and be contented. Further, he noted: 'There is the perfect will of God and the permissive will of God. This permissive will may provide temporary relief, howbeit not without complications.' Although professing Christianity, his response and the lesson he drew from it profess the Yoruba 'àyànmó ò gbó ògùn' - the irreversibility of predestination. What he terms the 'perfect will of God' is what Yoruba describe as 'the blessings of God that make a person succeed effortlessly' - 'ibùkún Olúwa níi mú ní là lài șe làálàá'. This blessing of God is different from what he termed the 'permissive will of God', which is a success, forcefully wrenched.

Yoruba say 'when an issue becomes knotty, refusing to be hung up or laid down, there is yet another option for its placement', 'tí ẹù ba k'ọkè, tí ó kọ ilè, ó tún ní ibi tíà'gbe sí. There is yet another outlet for that intractable problem that defies all solutions. That 'outlet' offers the temporary relief that Dr Alao speaks of. It comes, however, with significant side effects. These side effects only surface afterwards, as is artfully captured in the Yoruba film Egungun Be Careful, ${ }^{7}$ among others.

A wise woman, Iyami, meets Iya-Yomi sorrowing as she watches her neighbour's son give his aunt a car. Her only child, Yomi, is mired in misery and

\footnotetext{
${ }^{6}$ It is important to know that Dr Alao is my nickname for him, as are other subjects named in this article. It is the language of the informants that is of interest; it represents thoughts or things that are referenced.

${ }^{7}$ See <https://www.youtube.com/watch?v=t6Wq8wl5nSY>, accessed 18 February 2020.
} 
penury. Comforting her, Iyami says that the neighbour's son's success is due to great efforts undertaken for him by the aunt. 'She went out on it, she did a lot of trekking', ' $O$ jade si oro e, o de rin irin to po'. Iya-Yomi responds that she is ready to 'trek' to secure the success of her son. Iyami offers to help. They travel to the spiritual realm, where things that are not are caused to be. There, Iyami solicits unseen higher forces who grant her permission to present to Iya-Yomi a calabash that contains eggs of different colours, from which she is to choose one. She selects a white egg. Iyami congratulates her on her choice, then instructs her to touch the egg to her forehead. She does so and the egg vanishes into her head. Iyami breaks out in a witch's congratulatory song of success and says to her: 'From now on, your son has joined the league of the rich and wealthy. He will congregate with the powerful and dine with the famous. His money will be innumerable. I rejoice with you. Go home and relax. There is however one thing. Every three months, you will sleep with your son. You will continue to do so until the end of your days.' On hearing this, Iya-Yomi shudders, sinks to her knees, and begs for the process to stop. With a witch's laugh, Iyami tells her that there is no turning back. 'A kì i bó sínú omi tán ká máa sá fún òtútù', 'One cannot plunge into a river then complain of cold'. Iya-Yomi now pleads that her son be robbed of any consciousness of their copulation. Iyami grants her wish. Having sex with her son is now the side effect of this intervention. For the unknowing son, the side effect is his failed marriages. After copulating with his own mother, he becomes satiated and has no further urges. Even though he is attracted to many women, desires a family and marries several times, each wife eventually deserts him either following several months of unconsummated marriage or after catching him in the act with his mother.

The son's sexual life with his mother and his riches may be undetermined by the concept of ori, but they are not random and therefore not free. Without getting into the circular view of determinism precluding free will or choice, the result here is success, regardless of how it came about. This success is that 'other option' - in this case, Dr Alao's permissible will of God. This motif recurs in Yoruba movies and is a fixture of Yoruba habitual ethics. Owó ipá (forced riches), fífi agídí wá owó àti ợọ (seeking money and wealth by force) - where this is the source of a person's wealth, the end is often unpleasant.

Side effects are not always immediate; sometimes they manifest intergenerationally. In yet another dramatization, a very rich man is sleeping and dreaming of himself ablaze. He screams and wakes up to see his body being consumed by fire and he dies, burnt to death. His family, hearing his scream, rush in to find his charred remains writhing in the bed. He leaves behind enormous properties and businesses. Following his death, each of his children begins to experience sudden disappearances of money and valuables. All the money and valuables they touch vanish mysteriously. Frustrated, they consult a diviner and learn to their chagrin of a gnome whose job it is to retrieve from each of them anything of value. The diviner 'opens' their eyes and they see a vision of how their father had sought spiritual intervention to acquire riches. Unbeknownst to him (the deceased), his ori had chosen poverty. But because he was so desperate, the diviner whom he had consulted, desirous to help, called up for him the fortune of his children. He learns of this irreversible switch after the fact, saddened and burdened; there was no retreat. Since he has mortgaged the success of the next 
generation, the gnome's job is to balance the ledger by retrieving from his descendants all the riches he had expended, hence their misfortune.

\section{Ojú (eyes), ọwọ (hands), ẹsẹ (legs)}

The psychological relief that 'iṣe o kan oríire' offers to a person springs from a point of certitude that ori determines success, and not necessarily the individual. The die, one could say, was cast before conception. From birth, like a huge ball of yarn, the prescribed events contained in a person's orí begin to unravel. Knots, though unwanted, sometimes occur, and then the yarn needs to be unknotted. It is now no longer necessary to ask if the knot was part of the original design, an infelicity, or an intrusive enemy act. Yoruba allow for intrusion. The world, ilé-ayé, is full of evil or mysteries, ayé. It is the duty of ayé to cause knots in the otherwise straight yarn. God knew of this, so humans were equipped with oju (eyes) to 'watch over ori', 'ojú laafi ns'ori'. A person is not expected to stand idly by while their destiny unfolds but is to actively protect that destiny from the nefarious works of ayé. In this way, Gbadegesin (2004) concludes that ori is 'potential'. People must take active steps to actualize the pre-allotted by putting their limbs to use. According to Abimbola (2006), legs are a metaphor for work. Work includes offering sacrifices to unlock oríire (Abimbola 1977: 114ff.). Even the 'stop-gap' solution (e.g. in Iyami's story) requires work. Therefore, people are advised to 'take proactive steps', 'jáde s'ọrọ̀ ẹ'. Where success remains elusive despite 'trekking', they are told to trek some more $(f$ irin kún irin esé). Even so, they are aware that the efficacy of all 'endeavours', 'igbìyànju', depends on orí:

Mo fe se jije fun o
Mo fẹ șe wive
Mo fẹ se mimu
Mo fẹ di o
Eni ele eda re ba yan kadara ire
Afi ki ohun na ko ina mo
Gbogbo eni ti a ba n'ṣo fun
pe ola mbe ni iwaju re
Bi o ba ko ina mo kadara
O se se ki o ma fi eti gbo lasan

Mo fẹ se jije fun o

Mo fe se wiwe

Mo fe șe mimu

Mo fe di o

Afi ki ohun na ko ina mo

Gbogbo eni ti a ba n'ṣo fun

Bi o ba ko ina mo kadara

O se se ki o ma fi eti gbo lasan
I want to cook you a potion

I want to bathe you [in potion]

I want to brew you [a potion]

I want to fortify you

One predestined by their maker to good fortune

Must assiduously work at it

Everyone whose wealth we foretell

If they fail to diligently tend to their fate

It is possible for them to only hear of but never experience success

\section{To be: 'ṣe' or 'jẹ'}

The nature of the verb 'to be' - 'se' - is involved in the Yoruba view of success. Therefore, it is important to understand the permanence - or impermanence of the state it references. 'To be' is expressed by the verbs 'jẹ' and 'ṣe'. For instance:

\footnotetext{
Ișé [work] $k i i_{\text {[neg.] }} e_{\text {[to be] }}$ oriire ${ }_{\text {[success] }}$

Ade jé [is] omo [child] dada [good] Ade is a good person

Ade șe [is] omo dada

Ade acts responsibly
} 
These examples distinguish the two verbs: 'jẹ' appears to reference a permanent state, but not 'see', which, from the examples above, should be glossed as 'does'.
Ade jẹ [is] okunrin [male]
Ade is male
Funke jẹ [is] obinrin [female]
Funke is female
*FunkellAde șe [does] okunrin ${ }_{\text {[male] }}$
*Ade/Funke is male

Whereas the sex of Ade and Funke are each referenced by the verb 'jẹ' in the first two examples above, this is not so with the verb 's $e$ '; hence, it is marked as ungrammatical $\left(^{*}\right)$. However, this sentence becomes grammatical and an apt description of Ade and Funke, if rather than face ridicule, each committed suicide. In that sense, they acted in a 'manly' way. The deed is therefore the referent of 'se' in this context and not their indelible sex. The verb 'je', according to Barber (2007: 128), 'denotes the possession of an intrinsic quality, while the verb "se" denotes mutable conditions'. The claim that work is not success - i.e. 'ṣe' - does not mean that the converse is true: work is, 'jẹ', oriire. People are not absolved from labour.

Furthermore, in the simple but complex Yoruba saying 'bá ò kú iṣe [work]/ișe [deed] $o$ tán' are two critical views. First, until death, the destiny of a person is indeterminate. Every state of a person is transient. And second, the perfection, fullness, complete realization and unravelling of the content of ori comes at the moment of death. Until that exit point, labour continues. Labour continues for the regular person, who seeks to protect their oriiré from becoming oriburúkú and would readily 'walk' any distance to swap 'oriburúku' for 'oriire'. After all, 'good things need care, and the wanting requires attention', 'ohun tó dára nfé itợú, èyí tó kù diẹ káàtó nfẹ ìgbìyànjú'.

\section{Discussion and conclusion}

Yoruba orature recognizes money as integral to good fortune or success but perceives it more comprehensively. For instance, during the previously mentioned sixty-fifth birthday ceremony, an attendee, alàgbà Adeleke, wished us 'e o șe oriiré', 'may you be successful', as we were departing. I jokingly asked him for the meaning of oritiré. In response, he said:

There are three houses that humans can build on earth: a place of rest, where one is housed after the day's labour, moribidésí; an expanded residence to accommodate enlarging family members - spouses, children, servants and friends - àyè ò gbà wá; and a house built to impress others, àrà ni mo dá. ${ }^{8}$ Money makes all these possible. However, the ultimate oríiré is real contentment - àyò-ọàn. Perfected peace, rest and satisfaction that relieves one from the rat race - kìràkità. With àyò-okàn, the children of a demised person will dwell in unity and increase their family's achievements.

From this perspective, oriiré is in the ultimate contentment - a unification of money, children and longevity - and is marked by the person becoming an ancestor, memorialized through ritual activities, and able to reincarnate.

\footnotetext{
${ }^{8}$ Germans call this Augenweide, a feast for the eyes.
} 
The everyday orature informing this discussion is not exclusively the provenance of agrarian Yoruba; it is a timeless dynamic accompaniment, continuously derived from the reflections of the people in their peregrination, constantly reimagined without losing linkage with the pre-eminent drive of Yoruba existence, which to all intents and purposes appears immutable. Its retelling conversationally and didactically and its performance in films no doubt play a fair part in how they configure the apprehension of ori and the structuring of social life around it. What perhaps is variable in orature is the level of intensification and grip of the continuing directives towards their earthly pursuits at different times and in different places and space. Money, one of the three earthly blessings and life quests, aids the actualization of the self; but it is not the realization of the self. Yoruba recognize that wealth does not consist merely in the accumulation of money; to them, this is unstable, dependent on the vagaries of times, and therefore insecure. Humans are more lasting than money, so to be successful is to accumulate humans - wives for men, children for men and women, and men's and women's retinues of servants, hangers-on, praise singers and followers. Success/good fortune is further concretized in terms of land on which produce can be farmed or properties that can be rented out for gain. Aside from providing a visible sign of wealth, both farmland and landed properties are assets that are easily convertible to cash or can be traded to meet other needs. The final durable asset of wealth is one's own life. Longevity is the ground on which every aspiration rests. The conversion of short-term wealth - owó - to long-term value - orọ imbues the accumulated asset with sacredness. It removes it from trivial pursuit and confers it with dignity and honour - the mystiques of wealth. In this lies the difference between the confident repose of a settled aristocrat (bọrộkiní) and the brashness and exuberance of an upstart. In popular imagination, the one is almost divine, the other common, perhaps profane.

Yoruba fatalism or predestination and analogous concepts might be easily dismissed as irrational or nonsensical; however, such severe rational censure would be deceptive. In the case of a person, the notion that exertion does not determine fortune unravels important lessons about the strong bond between habits of the mind and cultural ideas in the apprehension and rationalization of life's troublesome inequity, especially of good or ill fortune. The Epicureans' view that all things are made up of atoms is akin to the Yoruba perception of ordination. The behaviour of the atom is governed by a fixed law. A thing constituted in this way is bound to the law governing the behaviour of the atoms. These atoms, however, are also susceptible to deviation from their predetermined path. For the Epicureans, personal choices occur and are located in those deviations. For Yoruba, the point of deviation offers intrusive aye the window of opportunity to steal or alter a person's orí. The reality of the co-extensiveness of ori and ayé with iṣe in Yoruba life has proven particularly intractable and resilient to the onslaught of received ideas and beliefs. To the dismay of realists, and to the consternation of 'Westernized minds' persuaded of personal control due to technological sophistication, this reality remains a centrepiece of explanations offered for sudden riches and unexpected failures. The Yoruba say there are herbs, there are charms; inefficacious medicine lacks but one herb. With this saying, they affirm their conviction in the efficacy of charms and herbs and their certainty that with the right combination of herbs, it is possible to re-purpose the ori of unsuspecting and unguarded individuals. 
The concrescence of fatalism and indeterminism in Yoruba life does not detract from the certitude of ori and the position of the limbs in life's journey. The progenitors and progenitrices who taught that 'medicine', ògùn, is effective did not neglect to add that 'sweat', óogùn, is extremely potent. 'God is not against padding it spiritually,' they say. 'Olọrun ò ko aájò.' Essentially, despite the surety of potions derived from a set formula, there is a chance that some higher force may prevent it from yielding the expected results - hence it is not perfected. For 'there is no charm against destiny', 'àyànmó ò gbọ ògùn'.

Consider a circle, which manifests circularity as its essence. Such a circle can become dented somewhere along its circumference and it would be recognized that such a dent was due to an external force and not because the circle chose to abandon its essence. That there are contingencies that impact on the essence of a person on earth suggests that an individual should not be evaluated alone but in consonance with others. Otherwise, the complete chain of causalities is lost. Yoruba are aware of this tunnel vision-like troubleshooting. Hence, they reflect not just on the current life of a person, but also on commissions and omissions of a person and their forebears (e.g. the man burning in his dream). Thus, seeking explanation for the immediate cause of good fortune or misfortune in this one life would be to focus mainly on the contingent rather than on its immanence. When so perceived, the distinction between determinism/ potentiality and free will of ori vanishes and the seeming contradiction within the Yoruba outlook is imperilled. The choice of ori would seem not to restrict freedom, which, in this case, would be acting in accordance with one's own orí. The stories of Iya-Yomi and the rich man show that humans act out of exigencies during their peregrination. And their view of success is relative to their immediate interests. The nature of the Yoruba ori thus appears inviolable, despite the immediate constraints denting the imaginary circle. Ori remains widely perceived as the bearer of a person's destiny, as illustrated by my visit to our neighbourhood.

Iya-eleedu (a female charcoal seller) is an extremely rich person in our neighbourhood in Ibadan and quite beloved. To come to Ibadan is to visit Iyaeleedu. Upon arrival, we met her settling disputes between some of her tenants. When we finally sat down in her living room, she hailed me by her term of endearment, akòwé (bookworm), then extolled orí gratefully for her position, which allowed her to have tenants:

Oluwa ni kole fun ni

Edumare lo mọ eniti yio ni òrùlé

Eni ba kole, ẹ ni ko fi ibà fun orí

Eleedu nkole, eleedu ndi landlord

Kini mo șe ti Edumare fi da mi lola

Kini mo nta' ti orí fi somi di onile?

God builds a house for a person

Only the creator knows who will own a roof

Whoever builds a house should give glory to ori

Charcoal seller owns properties, charcoal seller owns tenement houses

What have I done to be so blessed?

What is my trade for ori to make me a landlady? 
The data sampled from situational utterances, aphorisms, ifa verses and films, supplemented with basic linguistic insights and scholarly observations, are by no means exhaustive sources of knowledge on Yoruba everyday life. While other examples abound, the explored set of extant information uniformly shows the Yoruba's quotidian apprehension and valuation of the different range of favourable (oríiré) and unfavourable (oriburúkú) conditions that may chance upon a person.

\section{Acknowledgements}

I am thankful to numerous friends, acquaintances, neighbours and colleagues who over the years discussed isé o kan oriire with me. Special gratitude to Mr Kola Olunloyo, Mrs Margaret Olunloyo, Mr Jide Nelson, Mr Olaolu Omisore, Dr Anthony Chukwu, Professors Akin Alao, Toyin Falola and Durotoye Adeleke for their thoughts. I am alone responsible for all claims and representations in this article.

\section{References}

Abimbola, K. (2006) Yoruba Culture: a philosophical account. Birmingham: Iroko Academic Publishers.

Abimbola, W. (1971) 'The Yoruba concept of human personality' in La Notion de Personne en Afrique Noire. Collogues Internationaux de Centre National de la Recherche Scientifique. Paris: Centre National de la Recherche Scientifique.

Abimbola, W. (1977) Ifa Divination Poetry. New York NY: NOK.

Abiodun, R. (1981) 'Ori divinity: its worship, symbolism and artistic manifestation' in Proceedings of the World Conference on Orisa Tradition. Ife: Department of African Languages and Literatures, University of Ife.

Abiodun, R. (1987) 'Verbal and visual metaphors: mythical allusions in Yoruba ritualistic art of ori', Word and Image: A Journal of Verbal/Visual Enquiry 3 (3): 252-70.

Achebe, C. and C. L. Innes (eds) (1985) African Short Stories. London: Heinemann.

Akin-Makinde, M. (1984) 'An African concept of human personality: the Yoruba example', Ultimate Reality and Meaning 7 (3): 189-200.

Babatunde, E. D. (1992) A Critical Study of Bini and Yoruba Value Systems of Nigeria in Change: culture, religion, and the self. Lewiston NY: Edwin Mellen Press.

Balogun, A. B. (2007) 'The concepts of ori and human destiny in traditional Yorùbá thought: a soft-deterministic interpretation', Nordic Journal of African Studies 16 (1): 116-30.

Barber, K. (1997) Readings in African Popular Culture. Oxford and Bloomington IN: James Currey and Indiana University Press for the International African Institute.

Barber, K. (2007) The Anthropology of Texts, Persons and Publics. Cambridge: Cambridge University Press.

Bréal, M. (1995 [1884]) 'Comment les mots sont classés dans notre esprit' in $\mathrm{P}$. Desmet and P. Swiggers (eds), De la grammaire comparée à la sémantique. Textes de Michel Bréal publiés entre 1864 et 1898. Leuven and Paris: Peeters. 
Ekanola, A. B. (2006) 'A naturalistic interpretation of the Yorùbá concepts of Ori', Philosophia Africana 9 (1): 41-52.

Gbadegesin, S. (2003) 'Èniyàn: the Yoruba concept of a person' in P. H. Coetzee and A. P. J. Roux (eds), The African Philosophy Reader. 2nd edition. London: Oxford University Press.

Gbadegesin, S. (2004) 'Towards a theory of destiny' in K. Wiredu (ed.), A Companion to African Philosophy. Malden MA: Blackwell Publishing.

Gyekye, K. (1992) 'Person and community in Akan thought' in K. Wiredu and K. Gyekye (eds), Person and Community: Ghanaian philosophical studies. Volume 1. Washington DC: Council for Research in Values and Philosophy.

Gyekye, K. (1996) African Cultural Values. Accra: Sankofa Publication Company.

Hallen, B. and J. O. Sodipo (1986) Knowledge, Belief, and Witchcraft: analytic experiments in African philosophy. London: Ethnographica.

Hountondji, P. J. (1983) African Philosophy: myth and reality. 2nd edition. Translated by $\mathrm{H}$. Evans with the collaboration of J. Rée. Introduction by A. Irele. Bloomington and Indianapolis IN: Indiana University Press. (Originally published as Sur la 'philosophie africaine': critique de l'ethnophilosophie, 1976.)

Lakoff, G. (1974) 'Pragmatics in natural logic' in C. J. Fillmore et al. (eds), Berkeley Studies in Syntax and Semantics. Berkeley CA: University of California Press.

Lakoff, G. (1987) Women, Fire, and Dangerous Things: what categories reveal about the mind. Chicago IL: University of Chicago Press.

MacIntyre, A. (1981) After Virtue: a study in moral theory. Notre Dame IN: University of Notre Dame Press.

Makinde, M. A. (1985) 'A philosophical analysis of the Yoruba concept of ori and human destiny', International Studies in Philosophy 17 (1): 54-69.

McAdams, D. P. (1993) The Stories We Live By: personal myths and the making of the self. New York NY: William C. Morrow and Co.

Nyamnjoh, F. B. (2005) 'Fishing in troubled waters: disquettes and thiofs in Dakar', Africa 75 (3): 295-324.

Obiechina, E. (1972) An African Popular Literature: a study of Onitsha market pamphlets. London: Heinemann Educational.

Oduwole, E. (1996) 'The concepts of ori and human destiny', Journal of Philosophy and Development 1 (1-2): 40-52.

Oladipo, S. (1992) 'Predestination in Yoruba thought: philosopher's interpretation', Orita: Journal of Religion 24 (1-2): 34-51.

Owomoyela, O. (2005) Yoruba Proverbs. Lincoln NE: University of Nebraska Press.

Romney, A. K. and C. Moore (1998) 'Toward a theory of culture as shared cognitive structures', Ethos 26: 314-37.

Wiredu, K. (1980) Philosophy and an African Culture. Cambridge: Cambridge University Press.

\begin{abstract}
Work hard, work smart, make the right connections, get the right education, invest wisely - yet after doing all the supposedly right things, success remains elusive to
\end{abstract}


many. For a few, however, who may or may not have done exactly these things, success seems to come effortlessly. Some are very fortunate and others not so much. The lack of correspondence between exertion and success or work and good fortune is an issue that confronts lay persons and professionals alike. Focusing on Yoruba people, I discursively present lay Yoruba persons' apprehension and common-sense view of this conundrum as reflected in their contextualized language use and supported by other 'mundane' information from day-to-day life. By looking at their everyday language, it is possible to deduce their reality as socially constructed in their discourses and gain insight into how they reconcile individual exertions with a view that asserts determinism. Further, I will suggest that the basis of the Yoruba conventional knowledge system informing their utterances and actions pertaining specifically to people's earthly fortunes lies in their origination narrative and original life quest, the essence of which remains inarguable even if temporarily pliable. The popular saying 'isé o kan oríire', exertion does not relate to success, is used as a point of departure and sense contained in their orature - situational utterances, pithy proverbs, aphorism and anecdotes - to tease out the Yoruba ordinary meaning of success/fortune and how it is acquired, relative to individuals' earthly journey and preoccupation. Based on the sampled day-to-day utterances, individual life, it seems, unfolds as presumably scripted, despite apparent avowal and disavowal of ordination in people's pronouncements. Orí (head) retains its position at the summit, assenting - or not - to earthly endeavours.

\section{Résumé}

Même après avoir travaillé dur et avec intelligence, créé les bons liens, suivi les bonnes études, investi prudemment, autrement dit tout ce qu'il faut faire prétendument pour connaître le succès, beaucoup n'y parviennent pas. Pour quelques-uns, en revanche, qu'ils aient fait tout ce qu'il y avait à faire ou pas, le succès semble arriver sans effort. Certains ont beaucoup de chance et d'autres en ont moins. L'absence de rapport entre l'effort et le succès ou le travail et la chance est un problème que rencontrent les profanes comme les professionnels. Se concentrant sur les Yoruba, l'auteur présente de manière discursive l'appréhension et la vue de bon sens de ce dilemme par des profanes yoruba, telle que reflétée dans le langage contextualisé qu'ils utilisent et étayée par d'autres informations « banales » de la vie quotidienne. Le fondement du système de savoir conventionnel qui informe leurs déclarations et leurs actions réside dans l'origine du peuple yoruba, dont l'essence apparaît indiscutable, fût-elle temporairement flexible. La signification du succès/chance, la façon de l'acquérir et les préoccupations terrestres découlent de l'idéologie de l'origine des Yoruba et demeurent constantes, présumées fixes, malgré l'aveu et le désaveu d'ordination qui apparaissent dans les déclarations des personnes. La tête (orí) conserve sa position au sommet, consentant, ou pas, à des entreprises terrestres. 